
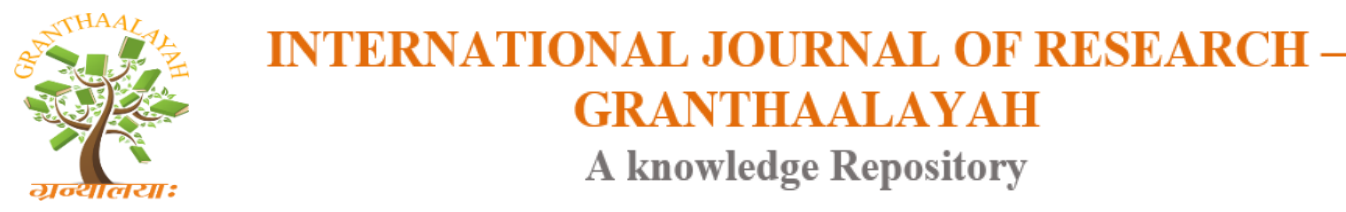

Science

\title{
INFORMATION USE PATTERN OF CIVIL AND MECHANICAL ENGINEERING FACULTY OF UNIVERSITY COLLEGE OF ENGINEERING AUTONOMOUS JNTUK KAKINADA: A STUDY
}

\author{
Doraswamy Naick B. R ${ }^{1}$, Venkateswara Rao Bavisetti ${ }^{2}$ \\ ${ }^{* 1}$ Associate Professor LIS, Dr B R Ambedkar Central Library, UCEK, Jawaharlal Nehru \\ Technological University, Kakinada, India \\ ${ }^{2}$ Library Assistant (Adhoc), Dr B R Ambedkar Central Library, UCEK, Jawaharlal Nehru \\ Technological University, Kakinada, India
}

\begin{abstract}
This Article to express the role of Web based information services of Civil and Mechanical Engineering faculty of University College of Engineering Autonomous Jawaharlal Nehru Technological University, Kakinada the Researcher has used the survey method to collect data from the University College of Engineering Autonomous faculty especially Regular Library users. The faculty are processed technically and tabulated as to the variables of the concerned topic of online resources.
\end{abstract}

Keywords: Information; Mechanical Engineering; Jntuk Kakinada.

Cite This Article: Doraswamy Naick B. R, and Venkateswara Rao Bavisetti. (2018). "INFORMATION USE PATTERN OF CIVIL AND MECHANICAL ENGINEERING FACULTY OF UNIVERSITY COLLEGE OF ENGINEERING AUTONOMOUS JNTUK KAKINADA: A STUDY." International Journal of Research - Granthaalayah, 6(9), 434-441. https://doi.org/10.5281/zenodo.1455800.

\section{Introduction}

Libraries and Information Resource centers have been serving web based information resources and services to their users. Library services, different type of databases, online databases, webbased services, and a multiplicity of other electronic media are replacing the established services of libraries. It also points out the need for assessing the impact of the Web based Services in the College, deemed to be University Libraries and University Libraries. College or Autonomous College Libraries launch their websites with a vision to offer services to users without their physical presence. In this paper an attempt is being made to bring to light the access to web-based Information services in the College Libraries Civil and Mechanical Engineering faculty of University College of Engineering Autonomous in particularly in recent past are providing some of notable information services that can be accessed via the College library websites are Web OPAC with Registered Login Account, latest advanced addition display, data search, access to full 
text and bibliographic databases, online document delivery, access to institutional repository and open access resources, databases and multimedia access resources, compilation of research profile, web based (current awareness services (CAS) and (Selective Dissemination of Information (SDI) Remote access and so on.

\section{About JNTUK}

JNTU (Jawaharlal Nehru Technological University) was originally 'The College of Engineering, Vizagpatnam' at the time of its establishment in 1946. It is now a sprawling campus of 110 acres, green with mango trees in the fast developing Port city of Kakinada, East coast of peninsula India. Kakinada has a rich political literacy and cultural heritage passed on through generations This college became a constituent of the Jawaharlal Nehru Technological University w.e.f 02-10-1972 through an act of legislature along with other sister institutions under the control of the then Director of Technical Education, Government of Andhra Pradesh. Earlier, it was affiliated to Andhra University. In the year 2003 the college has become autonomous.

The College is governed by the rules and guidelines provided by the university from time to time. The Principal is the administrative and the academic Head of the College. He is assisted by the Vice-Principal and the College Academic Committee in academic matters and the Deputy Registrar and the office staff in administrative matters. The day-to-day activities of the college are carried out by budgetary allocation from the University fund.

The entire academic activity in the college is overseen by the highest body called College Academic Council, which has at least one academician of repute and an industrialist on its body along with senior Professors of the college. Also the entire administrative activity is overseen by the highest body called College Governing Council (CGC) headed by the Vice Chancellor of the University.

The college has made rapid strides since its formation and is playing a pivotal role in the technological advances of the region.

All the five engineering departments are provided with RCC roof buildings. Additional accommodation for Electronics and Telecommunications Engineering, Computer Science \& Engineering and Electrical and Electronics Engineering departments is being provided through new buildings as annexes to the existing ones. Plans are afoot to accommodate teaching and nonteaching staff in newly constructed quarters in place of present 50 year old sheds.

The college provides hostel accommodation for nearly about 400 boys and 300 girls. Other amenities on the campus include Bank, Post-Office, dispensary, guesthouse, and play fields.

The Research and Development activity in the College got a boost with the procurement of modern and sophisticated equipment under MHRD and AICTE schemes. Academically, the post-graduate programmes introduced in 1971 in each of the available disciplines have undergone changes in course-structure and syllabi to meet the demands of the current needs. A new under-graduate programme in Computer Science and Engineering has been introduced subsequently. Another post-graduate programme is added in each of the disciplines along with one in Computer Science 
and Engineering. Now, the college has five U.G. Programmes and Nine P.G. Programmes to its credit. In addition the college helps unemployed under-employed diploma and degree holders in Engineering to improve their qualifications through its continuing education programmes.

The college has plans to provide an e-class room on each of Engineering Department. The college follows a continuous method of evaluation for internal assessment and external mode for endexaminations under semester system. Most of the faculty on rolls at present are having Ph.D and a few more are in the process of acquiring. The college, itself, has got the credit of producing a few $\mathrm{Ph}$.Ds through various research schemes within the available resources and those obtained from different funding agencies in addition to several M.Tech, M.S and a few M.Phil degrees. A few funded and sponsored research schemes have been in progress. Members of the teaching faculty have authored a good number of research papers, research reports and text-books. Departments in the college have conducted number of summer schools, seminars, workshops, symposia and conferences. In addition, quite a few collaborative research schemes sponsored by CSIR, CRRI, ISRO, BHEL etc have been/are being carried out.

The main library is situated in a separated block housing more than 54,000 volumes and contributed 12 numbers of journals maintained by two qualified librarians and necessary supporting staff for $12 \mathrm{hrs}$ a day for 6 days and 9 a.m to $1.00 \mathrm{pm}$ on Sunday. It is undergoing changes for automation. In addition, a book-bank with more than 3000 volumes is at the disposal of students for borrowing by BC, SC and ST categories. These books are procured from the funds provided by the Social Welfare Department. Over and above, each of the Engineering Departments have Departmental Libraries to reduce the burden on the Central Library and for the convenience of staff.

Several working/retired public and private sector organizations are benefited by consulting this college for technical advice. The College, also, made in roads into community development works by helping the local administrative authorities like municipalities, state police, endowments department, in designing drainage systems, traffic and pollution surveys, software development (e-cop) etc. The Civil Engineering department has got its additional accommodation with Rs.68.0 lakhs, half of which is from the amounts earned through consultancy. The Civil Engineering earns about 18 lakhs annually. With a few power projects coming up in the Private Sectors in and around Kakinada, a lot of Geotechnical investigation activity has been undertaken by the Civil Engineering Department. Some of important clients include ONGC, Kakinada Port Project, Sri Shakthi Gas Limited besides World Bank and Asian Development Bank (ADB) Aided Projects. The Mechanical Engineering Department offers consultancy works in the testing of pressure gauges, lubricating oils etc., and mineralogical investigations. The Electrical Engineering Department has been offering services in high voltage testing, calibration of meters, measurement of leakage currents in insulated High Voltage (HV) sticks and ladders and design of heavy current contactors.

The college successfully celebrated its Silver Jubilee in 1971. The college also celebrated its Golden Jubilee grandly during 1995 - 1996. With the help of funds raised through the contributions from the Alumni, a Golden Jubilee block (Swarnotsav Bhavan) has been constructed on the campus mainly to encourage Research \& Development activities. The college has presently 
entered into the Diamond Jubilee year. The celebrations from July 2005 - July 2006 will be land marked with academic and cultural activities.

\section{About Civil and Mechanical Engineering Department}

Department of Civil Engineering: was established in the Year 1946. The Department has created its own reputation through its teaching, research, consultancy and extensive activities. It offers Undergraduate program in Civil Engineering and Postgraduate Programs in Civil Engineering, Soil Mechanics and Foundation Engineering. The department is equipped with strength of materials and concrete technology, fluid mechanics and hydraulics machinery, geotechnical, environmental, surveying, transportation engineering, engineering geology and CAD and GIS laboratories. The department has advanced civil, computer application and geotechnical laboratories for post graduate students to perform research in respective areas. Civil engineering laboratory has compression testing machine with maximum capacity of $300 \mathrm{t}$, tensile testing machine and beam bending testing machine etc. to perform studies on different mixes of concrete and aggregates etc. The computational laboratory has STRAAP, STRUDS, MATLAB, Plaxis softwares etc. to perform numerical studies in civil and geotechnical areas. The advance geotechnical laboratory has cyclic tri-axial testing machine, large box shear apparatus to perform studies on various samples of soils.

Department of Mechanical Engineering: is established from the inception (1946) of the institute to meet the requirements of the mechanical industry and the society/discipline after the consultation with various stakeholders. The department started with an initial intake of 40 students in UG Program in ME and the intake is enhanced to 50 in the year 1976. In 1972, the department started a PG Program in "Machine Design (MD)" with an initial intake of 12 and the intake is enhanced to 18 students in the year 2001 again 18 to 25 in the year 2008. The department also started another PG Program in "Computer Aided Design and Computer Aided Manufacturing (CAD/CAM)" in the year 2001 with an initial intake of 18 and the intake is enhanced to 25 students in the year 2008.

A Sample survey conducted the Faculty of Civil and Mechanical Engineering Department at the University College of Engineering Jawaharlal Nehru Technological University Autonomous, Kakinada East Godavari District of Andhra Pradesh. The Researcher were asked about how they are using the library. They were also asked questions concerning their information use habits. The responses faculty is compared revealing expected and unexpected patterns.

Any library irrespective of its kind has to be user oriented. Information services provided by the library intended of the benefit of the users. In order to improve the existing library services, plan new services, rationalize the limited financial resources in an economic way, evaluate the performance of the library and enhance the user satisfaction, it is imperative to conduct user studies. These studies will help Faculty library authorities to know the satisfaction of users with the existing library services and facilities, the type of new services required and the amount of finance required for their implementation. 


\section{Information}

Information, communication and knowledge are essential for the development of the society. They are considered the wealth of society. In the contemporary society there is an ever increasing value for information. It is now considered an essential source for human development. Shera defines information as "information is a fact, it may be a single isolate fact, it may be a whole cluster of acts but it is still a unit, a unit of thought". Information is knowledge, intelligence and facts, which is the result of experience, observation, interaction and reading.

\section{Information Use Patterns}

Information use patterns are paths pursued by the individual in the attempt resolve a need. A study of user traits, of the study environment, and of information providers skill, is an important constituent of this new systematic approach. Ching-Chin chen has remarked that the information seeking patterns of an individual information environment, which consists of:

\section{Information Need}

The concept of information need has provided to be exclusive one and difficult to define. What initiates seeking need has received even more attention from researchers than definition of information. The topic also approached from such a variety of prospective that no single definition exists. In general, the literature falls into two broad categories some studies attempt to determine the nature of the need, while others attempt to distinguish between levels of perception. Researchers have used the term in a variety of ways, demands and wants have been used interchangeably although they may not be identical. Need is further complicated by the necessity to distinguish among expressed, unexpressed, or unfelt needs, the latter being the most difficult to identify. Based on information seeking behaviour, needs have been categorized as immediate or deferred. Another way of expressing this idea is to view 'need' as either shaped by activity.

\section{Information Seeking Behaviour}

The users may seek information is a number of ways such as reading books, periodicals, consulting abstracting and indexing periodicals, contacting colleagues and friends, seeking information from guides and senior co-workers, gathering information from library and information centers and attending seminars, conferences etc.

The studies to find out how a user seeks his information may help the library authorities to organize their acquisition programmes effectively and to introduce appropriate service.

\section{Statement of the Problems}

"Information Use Pattern of Civil And Mechanical Engineering Faculty Of University College Of Engineering Autonomous Jntuk Kakinada: A Study".

\section{Objectives of the Present Study}

The study has been conducted with the following objectives:

1) To find out the types of information sources required by the faculty members.

2) To find out the purpose for which they consult and collect information.

3) To identify the methods that the users of the library adopt to locate the required information sources. 
4) To ascertain the opinion of the users regarding the adequacy of library collection available in the library.

5) To ascertain the opinion of the faculty members regarding the adequacy of information resources and services available in the library.

6) To know the extent of satisfaction of faculty members with regard to e resources of Civil $\&$ Mechanical Engineering related, services and facilities provided by the library.

\section{Hypotheses}

The following are the hypotheses formulation.

- The present library collection is sufficient for Faculty requirements of information need.

- Faculties are satisfied with regard to Requirement of books on shelves.

- Faculty feels that orientation helps in the best utilization of information sources and services including e resources.

\section{Significance of the Study}

- The present study would throw light on the State-of-the-Art of Civil and Mechanical Engineering Faculty members University College of Engineering Autonomous with regard to the information use patterns.

- It is also highlights the current status of the library resources, services and facilities provided by the library.

\section{Use of the Present Study}

The use of the present study is to gain better understanding and identification of problems if any with the users for obtaining the information in order to improve the level of users of Dr B R Ambedkar Central Library resources services and facilities. Knowledge about the users, their information needs and access to quality and quantity of information for their study is prerequisite.

The Researcher would like to know the extent of user's or Faculty awareness of the sources, services and facilities provided by the library. In case they are not well aware of the facilities provided by the library the investigator wishes to make suggestions in this regard.

It is the duty is the Librarian and library authorities to put collection and services to the maximum use. Therefore it is intended to study the extent of using the library services by the users.

The present study is taken up to know the level of satisfaction of the faculty members regarding certain sources such as books, reference books, periodicals, newspapers, theses and dissertations, reports etc, services such as Circulation service, reference service, readers guidance service, inter library loan service, reprographic service, internet/e-mail service etc, and facilities such as arrangement of reading materials, space for reading, lighting and ventilation etc., and to know the reasons for their dissatisfaction if any, so that certain measures can be recommended.

Finally, it intends to get suggestions from the user's point of view for the improvement of the library collection, services and facilities. 


\section{Methodology}

\section{Selection of the sample}

There are two categories of users are using the Library they are:

1) Civil Engineering

2) Mechanical Engineering

3) The present study is limited to survey the Faculty of belonging to the Civil \& Mechanical Engineering.

\section{Contents of the Questionnaire}

It consists of the questions relating to the background information of the faculty members. It also consists of questions, to know the extent of use library resources, services and facilities provided by the library, the purpose for which they consult and collect the information, to know different sources for locating the documents, and the extent of satisfaction of library information sources, services and facilities provided by the library.

\section{Pilot Study}

A pilot study conducted with a sample of 30 questionnaires from faculty members of Civil and Mechanical Engineering and the results were tested. Based on the study, the questionnaire was further modified and developed to suit the stated objectives. According, revised questionnaire was finally administered.

\section{References}

[1] Adedibu L $\mathrm{O}$ and Adiou G. Information needs and information seeking patterns of medical students at Lautech, Ogbomoso. Aslib Proceedings. 49; 1997; 238-242.

[2] Brown, C. M., Information seeking behavior of scientists in the electronic information age: astronomers, chemists, mathematicians, and physicists. Journal of the American Society for Information Science, 1999, 50, (10), 929-943.

[3] Balasubramanian P. Information use pattern of faculty members in Madurai Kamaraj University. SREL Journal of Information Management. 45; 2008; 323-330.

[4] Doraswamy M. Information use patterns of postgraduate students: a case study at P.B. Siddhartha College of Arts and Sciences. Chinese Librarianship: an International Electronic Journal, 30; 2010.

[5] Finn, B., Johnston, P. Index use by engineering faculty and students. Georgia Library Quarterly, $2004,41,(3), 5-15$.

[6] Hallmark, J., Information-seeking behavior of academic meteorologists and the role of information specialists. Science \& Technology Libraries, 2001, 21, (1/2), 53-64.

[7] Kwasitsu, L., Information-seeking behavior of design, process, and manufacturing engineers. Library \& Information Science Research, 2003, 25, 459-476.

[8] Fidel, R., Green, M. The many faces of accessibility: engineers' perception of information sources. Information Processing and Management, 2004, 40, 563-581.

[9] https://smartech.gatech.edu/bitstream/handle/1853/28688/EngLibSurvey-Bear-Li.pdf

[10] Hemminger, Bradley M., Lu, Dihui, Vaughan, K.T.L., Adams, Stephanie J., Information seeking behavior of academic scientists. Journal of the American Society for Information Science \& Technology, 2007, 58, (14), 2205-2225.

[11] Haglund, L., Olsson, P., The impact on university libraries of changes in formation behavior among academic researchers: A multiple case study. The Journal of Academic Librarianship, 2008, 34, (1), 52-59. 
[12] Jamali, Hamid R., Nicholas, David, Information-seeking behavior of physicists and astronomers. Aslib Proceedings, 2008, 60, (5), 444-462.

[13] URL: http://www.iclc.us/cliej/cl30doraswamy.htm

[14] John (Jessi). Information needs, use pattern and use behaviour of Social researchers. Indian Journal of Library Science. 10; 1997; 79-80.

[15] Jamali, Hamid R., Nicholas, David, Information-seeking behavior of physicists and astronomers. Aslib Proceedings, 2008, 60, (5), 444-462.

[16] Seetha kumari P K. Information use pattern of researchers in pure sciences: a study of the Ph.D scholars of the University of Kerala. Kelpro Bulletin. 1; 1997; 27-39.

[17] Sethi (A R). Information seeking behaviour of social scientists; An Indian perspective. 1990. Hindustan pub. Co., Delhi.

[18] https://www.jntucek.ac.in/about

[19] http://www.jntuk.edu.in/about-jntuk/

\footnotetext{
*Corresponding author.

E-mail address: drnaickdora1970@gmail.com/vrbavisetti@gmail.com
} 